\title{
STUDY OF THE ADDITION HULL OF MUNG BEAN SPROUTS EXTRACT TO PH AND CHARACTERISTIC OF SENSORY YOGURT PROBIOTIC
}

\author{
Syifa Khairunnisa*, Indira Lanti Kayaputri, Gemilang Lara Utama \\ Department of Food Industrial Technology, Padjadjaran University, Jatinangor \\ Jalan Raya Bandung-Sumedang Km. 21, Jatinangor, Sumedang 40600, Indonesia \\ *Corresponding author: syifapaci@gmail.com
}

Accepted 22 August 2019; Revised 24 September 2019

Published 17 October 2019

\begin{abstract}
This research aims to determine the effect of adding hull of mung bean sprouts extract to $\mathrm{pH}$ and characteristics of sensory yogurt probiotic. The research method used experimental with randomized block design. There were 4 additional treatments $(1 \%, 2 \%, 3 \%$, and $4 \% \mathrm{w} / \mathrm{v}$ hull of mung bean sprouts extract) with 3 replications. The data obtained will be tested further using the Duncan test. The addition hull of mung bean sprouts extract has a significant different effect on the $\mathrm{pH}$ and color characteristics of yogurt probiotic while giving no significant effect on the characteristics of aroma, taste, texture and overall acceptance. Addition hull of mung bean sprouts extract affects the $\mathrm{pH}$ of yogurt probiotic produced which is about $4.00-4.11$. The color preferences of the yogurt probiotic are on the scale of dislike - really likes and preferences of the aroma, taste, texture and overall acceptance of yogurt probiotic are on the scale of usual - like. The conclusion of this study is that the addition hull of mung bean sprouts extract can prevent a decrease in $\mathrm{pH}$, causing a decrease in the level of preference for color and yogurt probiotic that produced is acceptable to consumers.
\end{abstract}

Keyword: Characteristics of sensory; hull of mung bean sprout; yogurt probiotic 


\section{INTRODUCTION}

Production probiotic yogurt generally uses the lactic acid bacteria Lactobacillus bulgaricus, Streptococcus thermophilus, and Lactobacillus acidophilus. Probiotic yogurt is one of the processed fermented milk which has better benefits than fresh milk because it can increase the growth of pathogenic bacteria and can be consumed by people who have lactose intolerance. Anyone who is lactose intolerant can consume yogurt because lactose is converted into glucose and galactose is fermented into lactic acid (Nikkhah, 2014). Apart from the health aspect, texture and sensory yogurt are also seen in consumer acceptance.

Probiotic yogurt has texture properties such as viscosity and smoothness which is an important attribute on consumer acceptance. Tamime and Robinson (2007) state that the common physical problems that occur in yogurt are the low level of viscosity, the emergence of syneresis and a decrease in the ability of water holding capacity. This can cause a decrease in consumer acceptance of probiotic yogurt. One of the efforts to reduce the emergence of syneresis is to be able to use existing polyphenols in plants.

Polyphenols are secondary metabolites of plants that can interact with proteins to produce a form of proteinpolyphenol complexes (Jakobek, 2015). Yildirim-Elikoglu and Erdem (2018) state that the function of proteins such as solubility and gel formation can change when interactions occur due to the addition of polyphenols. Polyphenol compounds have a strong attractive attraction for binding, and in some cases even precipitate proteins. Such interactions can cause microstructure changes in food as well as changes in functional characteristics of proteins and polyphenols (Unal et al, 2016). Polyphenols also can give a sensation of taste bitter and can affect the color of food. According to Rodriguez et al. (2009) polyphenols can affect sensory characteristics such as the aroma, flavour, and color of yogurt. However, polyphenols can also have inhibitory activity for the growth of yogurt bacteria. This inhibitory activity is related to changes in cell membranes and bacterial cell walls (Rodriguez et al., 2009).

Polyphenol compounds are capable of damaging cell membranes, activating enzymes, and denaturing cell proteins so that cell walls suffer damage due to decreased permeability resulting in stunted growth even to cell death (Damayanti and Suparjana, 2007 in Purwantiningsih et al., 2014). One of the plants that contain polyphenol compounds is green bean sprout skin (bean sprouts). Singh et al. (2017) stated that bean sprouts contain polyphenol compounds. Bean sprouts ( $\%$ dry matter) contain $3.41 \%$ ash, $9.56 \%$ crude protein, $47.77 \%$ crude fiber, crude fat $0.86 \%$, BETN $38.39 \%, \mathrm{Ca} 1.7 \%$ and $\mathrm{P} 0.28 \%$ (Rahayu, 2016).

Besides being based on nutritional content, the use of bean sprouts as an additional ingredient in yogurt is because the amount of bean sprouts in Indonesia is very large. Rahayu et al. (2010) informed that the total production of bean sprouts in the Bogor area is around 6.5 tons/day and has an opportunity to produce bean sprouts of 1.5 tons/day. When production bean sprouts, there was a release of mung bean skin and this part was not used by the community so
*Corresponding author:

Syifa Khairunnisa

Email: syifapaci@gmail.com

Departemen Teknologi Industri Pangan Universitas Padjadjaran, Jatinangor, Jalan Raya BandungSumedang Km. 21, Jatinangor, Sumedang 40600 , Indonesia
How to cite:

Khoirunnisa, S., Kayaputri, I. L., \& Utama, G. L. (2019). Study of the Addition Hull of Mung Bean Sprouts Extract to $\mathrm{pH}$ and Characteristic of Sensory Yogurt Probiotic. Jurnal Ilmu dan Teknologi Hasil Ternak, 14 (2), 99-106 
much that it became waste. Utilization of bean sprouts is still limited and not many data found the effect of bean sprouts on food products, especially yogurt.

Before testing the physical characteristics of probiotic yogurt, it is necessary to test the $\mathrm{pH}$ and consumer acceptance of probiotic yogurt added with bean sprouts. This $\mathrm{pH}$ test is carried out to determine the growth of the yogurt bacterial starter used. Bean sprouts, when dissolved in milk, is very easy to precipitate so that before the fermentation process will be filtered and left milk with bean sprouts extract. Therefore, this study aims to investigate the effect of adding bean sprout extract to the $\mathrm{pH}$ and sensory characteristics of probiotic yogurt.

\section{MATERIALS AND METHOD}

This research was conducted at the Food Processing Technology Laboratory, Faculty of Agricultural Industry Technology, Padjadjaran University. The ingredients used are bean sprouts from Cimahi bean sprout farmers, fresh cow's milk from the Faculty of Animal Husbandry, Padjadjaran University, sugar, freeze-dried starter Yogourmet, distilled water, buffer solution $\mathrm{pH} 4$ and $\mathrm{pH} 7$.

The tools used are stove, jar, pan, refrigerator, incubator, Shel Lab cabinet oven, Fomac Miller Machine grinder, 100 mesh stainless sieve, and Eutech Instruments $\mathrm{pH}$-meter. The research method used experimental with randomized block design. There were 4 treatments adding hull of mung bean sprouts extract $(1 \%, 2 \%, 3 \%$, and $4 \% \mathrm{w} / \mathrm{v}$ ) with 3 replications. The data obtained will be tested further using the Duncan test.

\section{Research stages}

\section{Bean sprouts flour production}

Bean sprouts are washed with clean water and then drained. Clean bean sprouts are placed on a baking sheet and then dried using a cabinet oven with a temperature of $50^{\circ} \mathrm{C}$ for $12 \mathrm{~h}$.
After that, the bean sprouts are turned into flour using a grinder and then sieved using a 100 mesh sieve. The purpose of making bean sprouts flour is to simplify the process of dissolving bean sprouts nutrition because the surface area of the bean sprouts increases.

\section{Starter production}

Fresh cow's milk is pasteurized with a temperature of $65 \pm 3^{\circ} \mathrm{C}$ for 30 minutes then the temperature is lowered to $40^{\circ} \mathrm{C}$. After that, aseptically inoculated with freeze-dried Yogourmet starter then incubated at $40 \pm$ $1^{\circ} \mathrm{C}$ for $6 \mathrm{~h}$.

\section{Flour bean sprout extract yogurt production}

Fresh cow's milk, bean sprouts flour and sugar $(3 \% \mathrm{w} / \mathrm{v})$ pasteurized at a temperature of $65 \pm 3^{\circ} \mathrm{C}$ for $30 \mathrm{~min}$ then the temperature is lowered to $40^{\circ} \mathrm{C}$. After that, aseptically inoculated with mother starter as much as $5 \%(\mathrm{w} / \mathrm{v})$ then incubated at $40 \pm 1{ }^{\circ} \mathrm{C}$ for $6 \mathrm{~h}$. Probiotic yogurt powder bean sprouts extract which has been finished is stored in the refrigerator at a temperature of $5 \pm 1^{\circ} \mathrm{C}$ for $12 \mathrm{~h}$ before testing.

\section{pH measurement}

Testing the $\mathrm{pH}$ of the yogurt using a $\mathrm{pH}$ meter that has been calibrated with two $\mathrm{pH} 7$ buffer solutions and a $\mathrm{pH}$ 4. The $\mathrm{pH}$ meter electrode dried with a tissue then rinsed with distilled water. Then the electrode dipped into the sample until the $\mathrm{pH}$ remains.

\section{Sensory characteristics measurement}

Sensory characteristics testing was carried out to determine the panelists' favorite responses to color, aroma, flavour, texture and overall acceptance of bean sprouts extract probiotic yogurt. This test based on a hedonic test conducted on 15 semi-trained panelists. Panelists were asked to provide an assessment of the sample with a 1-5 rating scale. Value $1=$ Very dislike, $2=$ Dislike, $3=$ Average, $4=$ Like and $5=$ Really like. 


\section{RESULTS AND DISCUSSION}

pH

The $\mathrm{pH}$ value is a measurement of the acidity level of the metabolism results of lactic acid bacteria. The activity of lactic acid bacteria will reorganize lactose to $80 \%$ lactic acid and some organic acids, causing a decrease in $\mathrm{pH}$ value due to a large number of dissolved $\mathrm{H}^{+}$ions. The results of probiotic yogurt $\mathrm{pH}$ testing with the addition of hull of mung bean sprouts flour extract can be seen in Table 1.

Table 1. Probiotic Yogurt $\mathrm{pH}$ with Addition of Hull of Mung Bean Sprouts Flour Extract

\begin{tabular}{cc}
\hline Treatment & $\mathrm{pH}$ \\
\hline $1 \%$ & $4.00 \pm 0.04^{\mathrm{c}}$ \\
$2 \%$ & $4.04 \pm 0.05^{\mathrm{bc}}$ \\
$3 \%$ & $4.08 \pm 0.00^{\mathrm{ab}}$ \\
$4 \%$ & $4.11 \pm 0.01^{\mathrm{a}}$ \\
\hline
\end{tabular}

The similar lowercase indiciates a nonsignificant difference $(\mathrm{P}>0.05)$

Based on Table 1. the different concentration of hull of mung bean sprouts flour extract gives a significantly different effect on the $\mathrm{pH}$ value. The probiotic yoghurt $\mathrm{pH}$ value of hull of mung bean sprouts flour extract is around 4.00-4.11 which is in accordance with the literature. According to Surono (2004), yogurt has a $\mathrm{pH}$ range of $4.0-4.5$. The different probiotic yogurt $\mathrm{pH}$ produced by the addition of hull of mung bean sprouts flour extract can be caused by the polyphenol content in hull of mung bean sprouts. The polyphenol content is thought to inhibit the growth of lactic acid bacteria. According to Singh (2017), extraction of hull of mung bean sprouts with water at $58^{\circ} \mathrm{C}$ for $182 \mathrm{~min}$ produced polyphenols with a total phenol of $16.05 \mathrm{mg}$ $\mathrm{GAE} / \mathrm{g}$ and a total flavonoid of $0.24 \mathrm{mg}$ QE/g.

According to Pacheco-Ordaz et al. (2017), the polyphenol component inhibits the growth of $L$. acidophilus. Strains of $S$. thermophilus and L. acidophilus show that they are very sensitive to the phenolic extract tested, including the fraction of grape seed extract at the lowest concentration (0.25 mg/mL) (Tabasco et al., 2011). $S$. thermophiles bacterium is a bacterium that first grows in milk and provides formic acid and $\mathrm{CO} 2$ components for the growth of $L$. bulgaricus and L. acidophilus bacteria at the beginning of milk fermentation (Sieuwerts, 2016).

The stunted growth of $S$. thermophilus by the addition of hull of mung bean sprouts flour extract can cause reduced activity of lactic acid bacteria so that the resulting $\mathrm{pH}$ is higher. Yogurt $\mathrm{pH}$ is caused by acid buildup due to the activity of lactic acid bacteria during the fermentation process. During the fermentation, lactic acid bacteria will change lactose into lactic acid (Djaafar and Rahayu, 2006). Lactose is broken down into glucose and galactose by the $\beta$ galactosidase enzyme. The glucose produced is then broken down into pyruvic acid through the glycolysis pathway, then the pyruvic acid by lactate dehydrogenase is converted to lactic acid (Palmiro, 2017). In addition, organic acids such as pyruvic acid and formic acid are also produced during the yogurt fermentation process and cause a decrease in acidity (Venica et al., 2014).

\section{Sensory characteristics Color characteristics}

Based on table 2. the different concentrations of hull of mung bean sprouts flour extract gives a significantly different effect on the preference of the probiotic yogurt. The average value of panelists' preference for the probiotic yogurt color of hull of mung bean sprouts flour extract ranged from 2.73 (dislike) - 4.33 (like). The addition of hull of mung bean sprouts flour extract reduces the color preference of the probiotic yogurt. The same results are obtained from yogurt drink with the addition of black tea extract which causes a decrease in color sensory compared with yogurt drink without the addition of black tea extract (Unal et al., 2016). Yogurt with hull of mung bean sprouts flour extract has a white brownish white color. This brownish color 
is due to mixing of the white color of milk and the brownish-yellow color of the hull of mung bean sprouts flour extract.

According to Singh (2017), the extraction of hull of mung bean sprouts with water at $58^{\circ} \mathrm{C}$ for 182 minutes produces polyphenol compounds in the form of catechin and quercetin. This brownish color can be caused by the degradation of chlorophyll and flavonoid compounds in the hull of mung bean sprouts. If in the leaves, a degradation process of chlorophyll occurs, it will make the color of the drink to become dark. The degradative product of chlorophyll in the form of pheophytin will cause the color of tea drinks to become dark. Water-soluble flavonoid compounds such as quercetin, which makes green tea to become yellow (Chaturvedula and Prakash, 2011).

\section{Aroma characteristics}

Based on Table 2 the different concentration of hull of mung bean sprouts flour extract gives no significant effect on the preference of the aroma of probiotic yogurt. The average value of panelists' preference for the probiotic yoghurt aroma of hull of mung bean sprouts flour extract ranged from 3.33 (normal) - 3.67 (like). The treatment of the addition of hull of mung bean sprouts flour extract does not affect the preference of the aroma on the probiotic yogurt. This can be caused by the typical aroma of acid which is very dominant in influencing the aroma of the probiotic yogurt. According to Panagiotidis and Tzia (2001), lactic acid, acetaldehyde, and diacetyl have a significant effect on the aroma characteristics of yogurt. This aroma is produced by the cooperation of Streptococcus thermophilus, Lactobacillus bulgaricus and L. acidophilus bacteria.

\section{Taste characteristics}

Based on Table 2 the different concentration of hull of mung bean sprouts flour extract gives no significant effect on the preference of the taste of probiotic yogurt. The average value of panelists' preference for the probiotic yogurt taste of hull of mung bean sprouts flour extract ranged from 3.53 (like) - 3.00 (normal).

The taste of this yogurt is slightly bitter sour, but the administration of hull of mung bean sprouts flour extract does not make a difference in the preference of the taste on the probiotic yogurt. This can be caused by the more dominant sour taste of yogurt formed. The sour taste is caused by lactic acid formed. Probiotic yogurt of hull of mung bean sprouts flour extract has lactic acid around $0.87 \%-0.93 \%$. According to Winarno and Fernandez (2007), lactic acid produced during the fermentation process can increase acidity and decrease $\mathrm{pH}$ of the milk. The treatment of the addition of hull of mung bean sprouts flour extract gives a significantly different $\mathrm{pH}$ value on the probiotic yogurt, but the consumer's preference for taste is not significantly different.

This can be caused by the $\mathrm{pH}$ of the resulting yogurt is still in accordance with the general $\mathrm{pH}$ standard of $4-4.5$, so that the $\mathrm{pH}$ value does not affect the consumer's preference for the taste of the probiotic yogurt. The bitter taste can be caused by polyphenol compounds in the hull of mung bean sprouts flour extract. According to Singh (2017), the extraction of hull of mung bean sprouts at $58^{\circ} \mathrm{C}$ for $182 \mathrm{~min}$ is detected to contain polyphenol compounds in the form of catechins. Catechin compounds provide a sharp and bitter sensation in green tea (Heijnen et al., 2000). According to Troszynska et al. (2006), eating foods that contain lots of polyphenols will cause a sharp sensation. Increased polyphenol content can reduce consumer's acceptance of the food.

\section{Texture characteristics}

Based on Table 2 the different concentrations of hull of mung bean sprouts flour extract gives no significant effect on the preference of the texture of probiotic yogurt. The average value of panelists' preference for the probiotic yogurt texture of hull of mung bean sprouts flour extract ranged from 3.07 (normal) - 3.53 (like). The 
texture of yogurt is seen from the panelists' preference for the thickness of hull of mung bean sprouts flour extract yogurt. This yogurt texture is thick. This is because, during fermentation, there is a decrease in $\mathrm{pH}$ and clumping of casein protein to form a gel. The formation of the gel causes the viscosity of the yogurt to increase and the texture of the yogurt to become thick (Foss, 2003). The formation of the texture of hull of mung bean sprouts flour extract yogurt can also be caused by cross-linking of polyphenols - proteins. According to Yildirim-Elikoglu and Erdem (2018), interactions between polyphenols and proteins can influence protein clumping and precipitation, so that it reduces protein solubility especially at $\mathrm{pH}$ values close to the isoelectric point of the protein.

\section{Overall acceptance characteristics}

Based on Table 2 the different concentrations of hull of mung bean sprouts flour extract gives no significant effect on the preference of the overall acceptance of probiotic yogurt. The average value of panelists' preference for the probiotic yogurt overall acceptance of hull of mung bean sprouts flour extract ranged from 3.07 (normal) - 3.87 (like). The hull of mung bean sprouts flour extract does not give a significant influence on the overall acceptance of the probiotic yogurt. This can be caused by the addition of hull of mung bean sprouts flour extract on the probiotic yogurt which does not have a significantly different effect on taste, aroma, and texture, but only gives a significantly different effect on the color of the probiotic yogurt.

Table 2. Sensory Characteristics of Probiotic Yogurt with Addition of Hull of Mung Bean Sprouts Flour Extract

\begin{tabular}{|c|c|c|c|c|c|}
\hline Treatment & Color & Aroma & Taste & Texture & $\begin{array}{l}\text { Overall } \\
\text { Acceptance }\end{array}$ \\
\hline $1 \%$ & $4.33 \pm 0.62^{\mathrm{a}}$ & $3.67 \pm 0.98^{\mathrm{a}}$ & $3.53 \pm 1.41^{\mathrm{a}}$ & $3.07 \pm 0.96^{\mathrm{a}}$ & $3.87 \pm 1.19^{\mathrm{a}}$ \\
\hline $2 \%$ & $3.00 \pm 1.20^{\mathrm{b}}$ & $3.53 \pm 1.06^{\mathrm{a}}$ & $3.27 \pm 0.96^{\mathrm{a}}$ & $3.20 \pm 1.37^{\mathrm{a}}$ & $3.27 \pm 0.96^{\mathrm{a}}$ \\
\hline $3 \%$ & $2.80 \pm 1.21^{\mathrm{b}}$ & $3.40 \pm 0.99^{\mathrm{a}}$ & $3.20 \pm 1.15^{\mathrm{a}}$ & $3.27 \pm 1.22^{\mathrm{a}}$ & $3.13 \pm 0.99^{\mathrm{a}}$ \\
\hline $4 \%$ & $2.73 \pm 0.96^{b}$ & $3.33 \pm 1.11^{\mathrm{a}}$ & $3.00 \pm 1.31^{\mathrm{a}}$ & $3.53 \pm 0.92^{\mathrm{a}}$ & $3.07 \pm 1.16^{\mathrm{a}}$ \\
\hline
\end{tabular}

The asimilar superscript indicates a non-significant difference $(\mathrm{P}>0.05)$ Preference value: $1=$ very dislike, $2=$ dislike $3=$ normal $4=$ like and $5=$ very like

The overall acceptance is an impression received from all product characteristics. The overall characteristics of yogurt products that affect consumer's acceptance are aroma, taste, appearance (color) and texture (Majchrzak et al., 2009). Based on the overall acceptance of hull of mung bean sprouts flour yogurt extract, it can still be accepted by consumers.

\section{CONCLUSIONS}

Based on the results of the study, it can be concluded that the addition of hull of mung bean sprouts flour extract can prevent a decrease in $\mathrm{pH}$, cause a decrease in the level of preference for color and produce probiotic yogurt that can be accepted by consumers. The treatment of $1 \%$ of probiotic yogurt of hull of mung bean sprouts flour extract is the treatment chosen and preferred by the panelists with product characteristics that have a $\mathrm{pH}$ of 4.00 and has a preference level of 4 (like) in color characteristics, while having a preference level of 3 (normal) to 4 (like) in aroma, taste, texture and overall acceptance characteristics.

\section{REFERENCES}

Chaturvedula, V. S. P., \& Prakash, I. (2011). The aroma, taste, color and bioactive constituents of tea. Journal of Medicinal Plants Research, 5(11), 2110-2124.

Djaafar, T. F., \& Rahayu, E. S. (2006). Karakteristik yoghurt dengan 
inoculum Lactobacillus yang diisolasi dari makanan fermentasi tradisional. Jurnal Pertanian Agros, 8(1), 73-80.

Foss, J. W. (2003). How Processing Affects Strach Selection For Yoghurt. In National Strach and Chemical Company. New York: Bridgewater.

Heijnen, C. G., Haenen, G. R. M., Wiseman, S. A., Tijburg, L. B., \& Bast, A. (2000). The interaction of tea flavonoids with the NO-system: discrimination between good and bad NO. Food Chemistry, 70(3), 365-370. https://doi.org/10.1016/S0308-8146(0 0)00105-9

Jakobek, L. (2015). Interactions of polyphenols with carbohydrates, lipids and proteins. Food Chemistry, 175, 556-567. https://doi.org/10.10 16/J.FOODCHEM.2014.12.013

Majchrzak, D., Lahm, B., \& Dürrschmid, K. (2010). Conventional and probiotic yogurts differ in sensory properties but not in consumers' preferences. Journal of Sensory Studies, 25(3), 431-446. https://doi.org/10.1111/j.174 5-459X.2009.00269.x

Nikkhah, A. (2014). Yogurt the most natural and healthy probiotic: history reveals. Journal of Probiotics \& Health, 2(2), 1-2. https://doi.org/10.4172/2329-890 $1.1000 \mathrm{e} 110$

Pacheco-Ordaz, R., Wall-Medrano, A., Goñi, M., Ramos-Clamont-Montfort, G., Ayala-Zavala, J., \& GonzálezAguilar, G. (2018). Effect of phenolic compounds on the growth of selected probiotic and pathogenic bacteria. Letters in Applied Microbiology, 66(1), 25-31. https://doi.org/10.1111/ lam. 12814

Palmiro, D. (2017). Microbiology in Dairy Processing (J. Wiley \& Son, Eds.). USA.
Panagiotidis, P., \& Tzia, C. (2001). Effect of Milk Composition and Heating on Flavor and Aroma of Yoghurt. In Food Flavor and Chemistry. UK: Cambridge.

Purwantiningsih, T. I., Suranindyah, Y. Y., \& Widodo. (2014). Activity of phenol of morinda citrifolia as natural antibacteria to inhibit the growth of mastitis-associated bacteria. Buletin Peternakan, 38(1), 59-64. https:// doi.org/10.21059/buletinpeternak.v38 i1.4618

Rahayu, S. (2016). Kajian Produktivitas dan Kesejahteraan Domba Garut dengan Pakan Limbah tauge dan Manajemen Pemberian Waktu Berbeda. Institut Pertanian Bogor.

Rahayu, S., Wandito, D. S., \& Ifafah, W. W. (2010). Survei Potensi Limbah Tauge Di Kota Madya Bogor. Institut Pertanian Bogor.

Rodríguez, H., Curiel, J. A., Landete, J. M., de las Rivas, B., de Felipe, F. L., Gómez-Cordovés, C., Muñoz, R. (2009). Food phenolics and lactic acid bacteria. International Journal of Food Microbiology, 132(2-3), 79-90. https://doi.org/10.1016/J.IJFOODMI CRO.2009.03.025

Sieuwerts, S. (2016). Microbial Interactions in the yoghurt consortium: current status and product implications. SOJ Microbiology \& Infectious Diseases, 4(2), 1-5. https://doi.org/10.15226/ sojmid/4/2/00150

Singh, B., Singh, N., Thakur, S., \& Kaur, A. (2017). Ultrasound assisted extraction of polyphenols and their distribution in whole mung bean, hull and cotyledon. Journal of Food Science and Technology, 54(4), 921-932. https://doi.org/10.1007/s13197-0162356-z 
Surono, L. S. (2004). Probiotik, Susu Fermentasi, dan kesehatan. Jakarta: Tri Cipta Karya.

Tabasco, R., Sánchez-Patán, F., Monagas, M., Bartolomé, B., Victoria MorenoArribas, M., Peláez, C., \& Requena, T. (2011). Effect of grape polyphenols on lactic acid bacteria and bifidobacteria growth: Resistance and metabolism. Food Microbiology, 28(7), 13451352. https://doi.org/10.1016/j.fm.20 11.06 .005

Tamime, A. Y., \& Robinson, R. K. (2007). Yoghurt Science and Technology (3rd ed.). UK: CRC Press.

Troszyńska, A., Amarowicz, R., Lamparski, G., Wołejszo, A., \& Baryłko-Pikielna, N. (2006). Investigation of astringency of extracts obtained from selected tannins-rich legume seeds. Food Quality and Preference, 17(12), 31-35. https://doi.org/10.1016/J. FOODQUAL.2005.04.006
Unal, G., Karagözlü, C., Kınık, O., Akan, E., \& Akalın, A. S. (2016). Influence of supplementation with green and black tea on viscosity and sensory characteristics of drinking yoghurt. Ege Üniversitesi Ziraat Fakültesi Dergisi, 53(3), 343-349.

Vénica, C. I., Perotti, M. C., \& Bergamini, C. V. (2014). Organic acids profiles in lactose-hydrolyzed yogurt with different matrix composition. Dairy Science \& Technology, 94(6), 561580. https://doi.org/10.1007/s13594014-0180-7

Winarno, F. G., \& Fernandez, I. E. (2007). Susu dan Produk Fermentasinya. Bogor: M-Brio Press.

Yildirim-Elikoglu, S., \& Erdem, Y. K. (2018). Interactions between milk proteins and polyphenols: Binding mechanisms, related changes, and the future trends in the dairy industry. Food Reviews International, 34(7), 665-697. https://doi.org/10.1080/875 59129.2017.1377225 